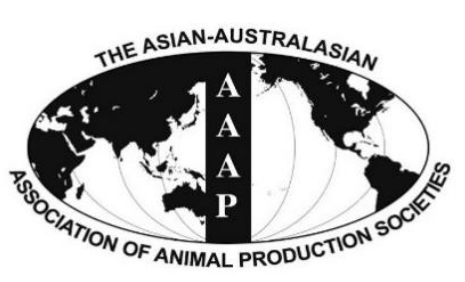

Open Access

Asian Australas. J. Anim. Sci.

Vol. 29, No. $3:$ 359-364 March 2016

http://dx.doi.org/10.5713/ajas.15.0429

www.ajas.info

pISSN 1011-2367 elSSN 1976-5517

\title{
Effects of Varying Levels of Fungal (Arachniotus sp.) Treated Wheat Straw as an Ingredient of Total Mixed Ration on Growth Performance and Nutrient Digestibility in Nili Ravi Buffalo Calves
}

\author{
F. Shahzad*, M. Abdullah', A. S. Chaudhry' ${ }^{2}$, J. A. Bhatti' ${ }^{1}$, M. A. Jabbar ${ }^{3}$, F. Ahmed ${ }^{4}$, \\ T. Mehmood ${ }^{4}$, M. Asim ${ }^{4}$, S. Ahmed ${ }^{5}$, Z. Kamran, I. Irshad ${ }^{6}$, and M. N. Tahir \\ University College of Veterinary and Animal Sciences, The Islamia University of Bahawalpur, \\ Bahawalpur 63100, Pakistan
}

\begin{abstract}
The study was carried out to explore the effects of replacing wheat straw with fungal treated wheat straw as an ingredient of total mixed ration (TMR) on the growth performance and nutrient digestibility in Nili Ravi buffalo male calves. Fungal treated wheat straw was prepared using Arachniotus sp. Four TMRs were formulated where wheat straw was replaced with 0 (TMR1), 33 (TMR2), 67 (TMR3), and 100\% (TMR4) fungal treated wheat straw in TMR. All TMRs were iso-caloric and iso-nitrogenous. The experimental TMRs were randomly assigned to four groups of male calves $(\mathrm{n}=6)$ according to completely randomized design and the experiment continued for four months. The calves fed TMR2 exhibited a significant improve in dry matter intake, average daily weight gain, feed conversion ratio and feed economics compared to other groups. The same group also showed higher digestibility of dry matter, crude protein, neutral-, and acid detergent fibers than those fed on other TMRs. It is concluded that TMR with $33 \%$ fungaltreated wheat straw replacement has a potential to give an enhanced growth performance and nutrient digestibility in male Nili Ravi buffalo calves. (Key Words: Arachniotus sp., Average Daily Gain, Fungal Treated Wheat Straw, Nili Ravi Buffalo Calves, Total Mixed Ration)
\end{abstract}

\section{INTRODUCTION}

The livestock sector is an imperative part of agriculture in Pakistan. Livestock accounted for approximately 55.9\% of agriculture value and $11.8 \%$ in country's gross domestic product during 2013 through 2014 (Pakistan Economics

\footnotetext{
* Corresponding Author: F. Shahzad. Tel: +92-629255567, Fax: +92-629255567, E-mail: faisalshehzad76@yahoo.com

${ }^{1}$ Department of Livestock Production, University of Veterinary and Animal Sciences, Lahore 42000, Pakistan.

${ }^{2}$ School of Agriculture, Food \& Rural Development, Newcastle University, Newcastle, NE1 7RU, UK.

${ }^{3}$ Pakistan Agriculture Research Board, Lahore 42000, Pakistan.

${ }^{4}$ Buffalo Research Institute, Pattoki 55300, Pakistan.

${ }^{5}$ Department of Animal Nutrition, University of Veterinary and Animal Sciences, Lahore 42000, Pakistan.

${ }^{6}$ Department of Pathology, University of Veterinary and Animal Sciences, Lahore 42000, Pakistan.

Submitted May 17, 2015; Revised Aug. 17, 2015; Accepted Sept. 26, 2015
}

Survey, 2014). The country has a huge population of livestock including cattle, buffalo, goat and sheep totaling approximately 172 million heads (Pakistan Economics Survey, 2014). The livestock are well adapted to subtropical environment, tolerant to endemic diseases and efficient convertors of poor quality forages into valuable products like milk, meat, skin, hides, bone and blood (Younas and Yaqoob, 2005). There is an utmost need to increase the livestock production potential to fulfill the growing demands of ever increasing population for livestock products. Amongst other factors, shortage of high quality feedstuffs and feeding of abundantly available poor quality dry roughages are the major constraints in the productivity of livestock sector (Sarwar et al., 2002).

Traditionally, crop residues contribute substantially nationwide to livestock feeding year around (Sarwar et al., 2002) but their proportion in the ration increases during periods of fodder scarcity. Wheat straw (WS), a crop 
residue that is emerging as a dominant feed source for a sustainable crop-livestock production system. It is also well known that WS is low in crude protein (CP) and energy, while its high fibre content limits voluntary intake to low levels in ruminants (Nisa et al., 2004). However, the low feeding value of WS could be improved through biotechnological methods (Selim et al., 2004) by carrying out fungal fermentation of WS in the presence of nonprotein nitrogen (urea) and soluble carbohydrates (e.g. molasses). Different kinds of fungi have been used to improve the nutritive value of industrial by-products or highly fibrous agricultural wastes. Growth of fungal mycelium was previously found to enhance total protein contents in fermented feed (Fazaeli and Mirhadi, 2007). However, long incubation periods and slow degradation of fiber components during fermentation are main drawbacks of fungal application for nutritive improvement of WS.

Among the family members, Arachniotus fungi could be used to upgrade the nutritional value of fibrous feeds, especially in combination with solid state fermentation technology. Arachniotus sp. is a white rot fungus and has been used for the economic utilization of many waste products (Shaukat et al., 2006). The higher production of microbial biomass protein by fermentation of corn stover with Arachniotus sp. was already observed by Ahmed et al. (2010). And the potential utilization of corn stover can minimize the cost for growth of these microorganisms and enhance microbial biomass protein production by fermentation. The microbial biomass protein increases by utilizing the cellulose and hemi-cellulose of the substrate as an energy source for synthesis of protein. These methods are preferable due to their simplicity, specificity and circumventing the disadvantages of physical and chemical treatments (Misra et al., 2007). But the application of these methods at farm level in a livestock production system is very limited especially in developing countries like Pakistan. Undoubtedly, research is being carried out since the last decade to exploit the nutritive potential of fungal treated crop residues but is restricted to the laboratory level in Pakistan and there is not even a single feeding trial reported at the farm level in ruminants.

The present study gives the opportunity to evaluate varying levels of fungal treated WS as an ingredient of total mixed rations (TMR) on growth performance and nutrient digestibility in Nili Ravi buffalo calves. The purpose was to elucidate the potential of replacing the conventional feeding management practice with novel biotechnological methods and its effects on palatability and economic value of the diet.

\section{MATERIALS AND METHODS}

\section{Animals and experimental design}

The present study was conducted according to the guidelines of the Committee on Use of Animals in Research and Experimentation. Twenty four Nili Ravi buffalo male calves with the average age 9 to 12 month and a live body weight $112 \pm 7 \mathrm{~kg}$ were selected at Buffalo Research Institute, Pattoki, Kasur, Pakistan. The animals were tied and maintained in separate pens with individual feeding. Fresh clean drinking water was provided ad libitum during the whole experimental period. Animals were allocated in four groups in a completely randomized design and the experiment continued for four months.

\section{Preparation of fungal treated wheat straw}

Fungal treated WS was prepared according to the method described (Faisal Shahzad, personal communication). Briefly, WS with at a chop length of 2.5 to $3.0 \mathrm{~cm}$ was bedded on polythene cemented plotted covered room $(4 \times 4 \mathrm{~m})$ with an adjustment of 24 electric rods (500 watt each) in criss-cross arrangement to control the temperature. Wheat straw (about $80 \mathrm{~kg}$ ) was placed in a pre-fumed room and subjected to spraying of $105.6 \mathrm{~L}$ water solution containing $\left(\mathrm{MgSO}_{4} .7 \mathrm{H}_{2} \mathrm{O}[40 \mathrm{~g}], \mathrm{CaCl}_{2}[60 \mathrm{~g}]\right.$, $\mathrm{KH}_{2} \mathrm{PO}_{4}\left[\begin{array}{ll}120 & \mathrm{~g}\end{array}\right]$ urea $\left.\left[\begin{array}{ll}120 & \mathrm{~g}\end{array}\right]\right)$ and inoculated with Arachniotus sp. (5 L inoculums). At $48 \mathrm{~h}$ of start of the experiment, molasses $(6.4 \mathrm{~L})$, rice polishing $(12.8 \mathrm{~kg})$ and corn steep liquor $(48.0 \mathrm{~L})$ were added to enhance the fermentation process. The incubation period continued for 4 days at approximately $28^{\circ} \mathrm{C}$.

\section{Treatments and experimental design}

Four experimental TMR were formulated where WS was replaced with 0\% (TMR1), 33\% (TMR2), 67\% (TMR3), and 100\% (TMR4) fungal treated WS using the ingredients presented in Table 1. The experimental TMRs were randomly assigned to four groups of male calves $(\mathrm{n}=$ 6) according to completely randomized design. The TMRs were prepared according to National Research Council recommendations (NRC, 2001) for CP and energy for the growing animals and contained similar concentrations of $\mathrm{CP}$ (13.5\%) and energy $(2.4 \mathrm{Mcal} / \mathrm{kg})$ on dry matter basis. The diets were offered ad libitum once daily and daily feed intake was recorded for individual animals during the sampling period. The residual feed from the feeding troughs was removed once per day. The ingredient and chemical compositions of all TMR are presented in Table 2.

\section{Sampling and chemical analysis}

Samples of TMR and feces were collected as per guidelines and stored at $-20^{\circ} \mathrm{C}$ until analysis. TMR and fecal samples were analyzed for dry matter (DM), CP, and ash according to the procedures of Association of Official Analytical Chemists (AOAC, 2006). Neutral detergent fiber (NDF) and acid detergent fiber (ADF) and acid detergent lignin were determined according to the methods of Van 
Table 1. Chemical composition of the ingredients

\begin{tabular}{lcccccccccccc}
\hline Ingredients & $\begin{array}{c}\text { Maize } \\
\text { silage }\end{array}$ & $\begin{array}{c}\text { Fungal treated } \\
\text { wheat straw }\end{array}$ & $\begin{array}{c}\text { Wheat } \\
\text { straw }\end{array}$ & $\begin{array}{c}\text { Maize } \\
\text { Broken }\end{array}$ & $\begin{array}{c}\text { Wheat } \\
\text { bran }\end{array}$ & $\begin{array}{c}\text { Cotton } \\
\text { seed } \\
\text { cake }\end{array}$ & $\begin{array}{c}\text { Maize } \\
\text { gluten } \\
\text { meal 30\% }\end{array}$ & $\begin{array}{c}\text { Rapeseed } \\
\text { cake }\end{array}$ & $\begin{array}{c}\text { Corn } \\
\text { steep } \\
\text { liquor }\end{array}$ & $\begin{array}{c}\text { Cane } \\
\text { molasses }\end{array}$ & $\begin{array}{c}\text { Mineral } \\
\text { mix }\end{array}$ & $\begin{array}{c}\text { Urea } \\
\text { DM }\end{array}$ \\
\hline 30 & 92 & 92 & 89 & 89 & 90 & 91 & 90 & 50 & 74 & 100 & 100 \\
CP & 8 & 13 & 1.9 & 9 & 15 & 20 & 29 & 35 & 35 & 2 & 0 & 288 \\
NDF & 46 & 37 & 76 & 10 & 43 & 50 & 36 & 30 & 0 & 0.4 & 0 & 0 \\
ADF & 25 & 22 & 56 & 3 & 16 & 10 & 10 & 21 & 0 & 0 & 0 & 0 \\
ADL & 2.25 & 4.3 & 8.2 & 0.9 & 3 & 12 & 1.5 & 7.4 & 0 & 0 & 0 & 0 \\
Ash & 7 & 19 & 9 & 7 & 6 & 4 & 5 & 7 & 10 & 13 & 100 & 0 \\
ME & 2.58 & 2.1 & 1.55 & 3.1 & 2.5 & 2.29 & 3.03 & 2.75 & 1.8 & 2.78 & 0.0 & 0.0 \\
\hline
\end{tabular}

The values are expressed as \% age of dry matter unless otherwise stated.

$\mathrm{DM}$, dry matter; CP, crude protein; NDF, neutral detergent fiber; ADF, acid detergent fiber; ADL, acid detergent lignin; ME, metabolizable energy (MCal/kg DM).

Soest et al. (1991).

\section{Data recording and statistical analysis}

Feed intake was recorded daily and live body weight fortnightly with digital weighing bridge. Feed conversion ratio (FCR; $\mathrm{kg}$ feed/kg gain) and feed economics (return from body gain/total feed cost) were calculated. The digestibility trial was carried out by total collection method during which total feces were collected for 5 consecutive days. Digestibility for DM, CP, and NDF which is hereby

Table 2. Ingredient and chemical composition of the experimental total mixed rations

\begin{tabular}{lcccc}
\hline \multirow{2}{*}{ Items } & \multicolumn{4}{c}{ Experimental total mixed rations } \\
\cline { 2 - 5 } & TMR1 & TMR2 & TMR3 & TMR4 \\
\hline Ingredients & 22.0 & 22.0 & 22.0 & 22.0 \\
Maize silage & 0.0 & 7.3 & 14.7 & 22.0 \\
Fungal treated wheat straw & 22.0 & 14.7 & 7.3 & 0.0 \\
Wheat straw & 23.5 & 10 & 14.5 & 0.5 \\
Maize broken & 0.5 & 8.0 & 16.0 & 34.0 \\
Wheat bran & 13.0 & 9.0 & 4.0 & 0.5 \\
Cotton seed cake & 2.0 & 14.0 & 14.5 & 9.0 \\
Maize gluten meal 30\% & 10.0 & 6.5 & 0.5 & 1.0 \\
Rapeseed cake & 3.5 & 1.0 & 3.0 & 2.0 \\
Corn steep liquor & 2.0 & 6.5 & 2.5 & 8.0 \\
Cane molasses & 1.0 & 1.0 & 1.0 & 1.0 \\
Mineral mix & 0.5 & 0.0 & 0.0 & 0.0 \\
Urea & & & & \\
Chemical composition & 75.5 & 75.9 & 75.5 & 75.0 \\
Dry matter & 13.7 & 13.6 & 13.7 & 13.6 \\
Crude protein & 39.5 & 39.8 & 36.6 & 36.5 \\
Neutral detergent fiber & 22.2 & 20.5 & 17.6 & 16.7 \\
Acid detergent fiber & 8.2 & 8.9 & 9.5 & 10.7 \\
Ash & 2.40 & 2.47 & 2.51 & 2.47 \\
Metabolizable energy & & & & \\
(Mcal/kg DM) & 19.8 & 19.5 & 19.5 & 19.4 \\
Price/kg feed & & & & \\
\hline
\end{tabular}

The values are expressed as \% age of dry matter unless otherwise stated. TMR, total mixed ration. denoted by $\mathrm{X}$ was calculated according to the following equation:

$$
\begin{aligned}
& \text { Digestibilty }(X) \\
= & \left(\frac{\text { Dietary concentrarion of } X-\text { Fecal concentration of } X}{\text { Dietary concentration of } X}\right) \times 100
\end{aligned}
$$

Data from the feeding trial were analyzed according to Completely Randomized Design using general linear model procedure of SAS 9.2 software (SAS, 2008; SAS User Manual, Version 9.2. SAS Inst. Inc., Cary, NC, USA). Each animal on a specific TMR was considered as the experimental unit. The linear and quadratic effects of increasing level of fungal treated WS in the diet were examined by replacing the qualitative variable diet in the model with the quantitative variable proportion of fungal treated WS using Fitted Line Polynomial Regression Analysis in MINITAB (version 16.1.1.0). Data are presented as mean \pm standard error of mean. The level of significance was set at $\mathrm{p}<0.05$.

Following mathematical model was applied:

$$
\mathrm{Y}_{\mathrm{ij}}=\mu+\tau_{\mathrm{i}}+\varepsilon_{\mathrm{ij}}
$$

Where, $\mathrm{Y}_{\mathrm{ij}}=$ each observation on $\mathrm{j}^{\text {th }}$ animal due to $\mathrm{i}^{\text {th }}$ treatment

$$
\begin{aligned}
& \mu=\text { overall mean } \\
& \tau_{\mathrm{i}}=\text { effect of } \mathrm{i}^{\text {th }} \text { treatment }\left(\sum \tau_{\mathrm{i}}=0 \text { and } \mathrm{i}=1,2,3,4\right)
\end{aligned}
$$

$\varepsilon_{\mathrm{ij}}=$ random error associated with $\mathrm{i}^{\text {th }}$ treatment with the restriction that variance $\sigma^{2}$ and mean zero.

\section{RESULTS}

Fungal treatment of WS increased CP and ash contents while cell wall contents were reduced (Table 1). The results showed that TMR2 improved $(\mathrm{p}<0.001)$ average daily gain $(A D G)$ of the calves and feed economics $(p<0.001)$ and FCR $(p<0.001)$ (Table 3). The increasing level of fungal treated WS produced quadratic effects on all these 
Table 3. Effects of fungal treated wheat straw supplementation as a part of total mixed ration on growth performance, feed conversion ratio and feed economics of Nili Ravi buffalo calves

\begin{tabular}{|c|c|c|c|c|c|c|c|c|}
\hline \multirow{2}{*}{ Parameters } & \multicolumn{4}{|c|}{ Experimental total mixed rations ${ }^{1}$} & \multirow{2}{*}{ SEM } & \multicolumn{3}{|c|}{ p-value } \\
\hline & TMR1 & TMR2 & TMR3 & TMR4 & & TMR & $\mathrm{L}$ & $\mathrm{Q}$ \\
\hline$\overline{\mathrm{ADG}(\mathrm{kg} / \mathrm{d})}$ & $0.52^{\mathrm{ab}}$ & $0.56^{\mathrm{a}}$ & $0.51^{\mathrm{b}}$ & $0.48^{\mathrm{b}}$ & 0.011 & $<0.001$ & 0.010 & 0.019 \\
\hline FCR (kg feed/kg gain) & $5.49^{\mathrm{a}}$ & $5.27^{\mathrm{b}}$ & $5.49^{\mathrm{a}}$ & $5.57^{\mathrm{a}}$ & 0.033 & $<0.001$ & 0.050 & 0.004 \\
\hline Cost/kg gain & $108.8^{\mathrm{a}}$ & $103.2^{\mathrm{b}}$ & $107.0^{\mathrm{a}}$ & $107.9^{\mathrm{a}}$ & 0.61 & $<0.001$ & 0.808 & 0.001 \\
\hline $\begin{array}{l}\text { FE } \\
\text { (return from body gain/total feed cost) }\end{array}$ & $1.38^{\mathrm{b}}$ & $1.44^{\mathrm{a}}$ & $1.38^{\mathrm{b}}$ & $1.36^{\mathrm{b}}$ & 0.008 & $<0.001$ & 0.057 & 0.001 \\
\hline
\end{tabular}

All values are mean \pm SEM. Data represent the average of 6 animals in each group.

TMR, total mixed ration; SEM, standard error of mean; L, linear effect of increasing fungal treated wheat straw in TMR; Q, quadratic effect of increasing fungal treated wheat straw in TMR; ADG, average daily gain; FCR, feed conversion ratio; FE, feed economics.

${ }^{1}$ TMR1, TMR2, TMR3, and TMR4 represent $0 \%, 33 \%, 67 \%$, and $100 \%$ replacement of wheat straw with fungal treated wheat straw respectively.

parameters.

Replacing 33\% WS with fungal treated WS in TMR2 showed the greatest intakes of DM, CP, and NDF by calves as depicted in Table 4. The intake of ADF was the highest in the control group (TMR1). Data also showed that the increasing level of fungal treated WS had linear effects on DM, CP, NDF, and ADF intakes (Table 4). The digestibilities of $\mathrm{CP}, \mathrm{NDF}$, and ADF were the highest for calves fed the TMR2 diets and linearly influenced by the increasing levels of fungal treated WS.

\section{DISCUSSION}

The lower NDF and ADF contents might be an indication of cell wall breakdown due to Arachniotus sp. The increased ash may be due to the added minerals that had to be used in the medium to grow Arachniotus sp.

The increases in ADG and feed economics on TMR2 diets might be due to favorable increase in DM intake, improvement in the digestibility of all nutrients and may have been related to improved nitrogen status of animals.
Further increase in fungal treated WS in TMR beyond this level led to decrease in ADG that corresponds well to decrease in DM intake. The reasons for this phenomenon were not clear. The relatively high ash content in TMRs with $67 \%$ and $100 \%$ fungal treated WS replacements might have resulted in reduced palatability of the diet; this could be one explanation to the underlying phenomenon. Fazaeli and Shafeyi (2003) concluded that WS could be supplemented with Agaricus bisporus up to $15 \%$ for finishing lambs beyond which nutrient balance is reduced due to high mineral contents. The results of the current study correspond well with those of several authors previously reporting the effectiveness of fungal treatments in different diets. Pleurotus ostreatus treated maize straw led to a $17.5 \%$ increase in ADG in Pelibuey lambs compared to control diet (Ramírez-Bribiesca et al., 2010). Similarly, significant increases in DM intake and growth rate were observed in West African dwarf lambs fed biologically treated maize cobs replacing wheat offal in guinea grass (Panicum maximum) based diets (Akinfemi and Ladipo, 2011). Abdel-Azim and co-authors (2011)

Table 4. Effects of fungal treated wheat straw supplementation as a part of total mixed ration on nutrients intake and digestibility in Nili Ravi buffalo calves

\begin{tabular}{|c|c|c|c|c|c|c|c|c|}
\hline \multirow{2}{*}{ Parameters } & \multicolumn{4}{|c|}{ Experimental total mixed rations $^{1}$} & \multirow{2}{*}{ SEM } & \multicolumn{3}{|c|}{ p-value } \\
\hline & TMR1 & TMR2 & TMR3 & TMR4 & & TMR & $\mathrm{L}$ & Q \\
\hline \multicolumn{9}{|l|}{ Intake (kg/d) } \\
\hline Dry matter & $2.88^{\mathrm{ab}}$ & $2.95^{\mathrm{a}}$ & $2.80^{\mathrm{ab}}$ & $2.71^{\mathrm{b}}$ & 0.049 & $<0.01$ & 0.009 & 0.125 \\
\hline Crude protein & $0.39^{\mathrm{ab}}$ & $0.40^{\mathrm{a}}$ & $0.38^{\mathrm{ab}}$ & $0.37^{\mathrm{b}}$ & 0.007 & $<0.01$ & 0.006 & 0.076 \\
\hline $\mathrm{NDF}$ & $1.14^{\mathrm{a}}$ & $1.17^{\mathrm{a}}$ & $1.02^{\mathrm{b}}$ & $0.99^{\mathrm{b}}$ & 0.018 & $<0.001$ & 0.001 & 0.136 \\
\hline $\mathrm{ADF}$ & $0.64^{\mathrm{a}}$ & $0.60^{\mathrm{a}}$ & $0.49^{\mathrm{b}}$ & $0.45^{\mathrm{c}}$ & 0.010 & $<0.001$ & 0.001 & 0.784 \\
\hline \multicolumn{9}{|l|}{ Digestibility (\%) } \\
\hline Dry matter & $64.5^{\mathrm{ab}}$ & $69.3^{\mathrm{a}}$ & $64.0^{\mathrm{ab}}$ & $60.9^{\mathrm{b}}$ & 1.29 & $<0.01$ & 0.093 & 0.030 \\
\hline Crude protein & $74.1^{\mathrm{ab}}$ & $77.2^{\mathrm{a}}$ & $72.9^{\mathrm{bc}}$ & $69.7^{\mathrm{c}}$ & 0.92 & $<0.001$ & 0.020 & 0.016 \\
\hline $\mathrm{NDF}$ & $54.1^{\mathrm{ab}}$ & $59.2^{\mathrm{a}}$ & $50.7^{\mathrm{ab}}$ & $44.0^{\mathrm{b}}$ & 2.49 & $<0.01$ & 0.019 & 0.049 \\
\hline $\mathrm{ADF}$ & $44.6^{\mathrm{ab}}$ & $48.6^{\mathrm{a}}$ & $40.7^{\mathrm{ab}}$ & $38.8^{\mathrm{b}}$ & 1.89 & $<0.01$ & 0.026 & 0.250 \\
\hline
\end{tabular}

All values are mean \pm SEM. Data for intake represent the average of 6 and those for digestibility represent the average of 3 animals in each group, respectively.

TMR, total mixed ration; SEM, standard error of mean; L, linear effect of increasing fungal treated wheat straw in TMR; Q, quadratic effect of increasing fungal treated wheat straw in TMR; NDF, neutral detergent fiber; ADF, acid detergent fiber.

${ }^{1}$ TMR1, TMR2, TMR3 and TMR4 represent $0 \%, 33 \%, 67 \%$, and $100 \%$ replacement of wheat straw with fungal treated wheat straw respectively. 
found a greater DM intake and an improved nitrogen balance in cross-bred lambs fed rice straw and corn stalks treated with Trichoderma viride. Kim et al. (2011) found that supplementing Oyster mushroom (Pleurotus ostreatus) spent substrate with selective lactic acid producing bacteria at the rate of $10 \%$ in calf starter diet improved the ADG in post weaning calves.

The reduced FCR exhibited by calves fed TMR2 diets is mainly attributable to improved nutritive value and better palatability as reflected by improved growth performance of the experimental animals; this is in agreement with the results of others (El-Kady et al., 2006). Similar results for FCR were found by Salman et al. (2008) in goats fed fungal treated sugar beet pulp. Fouda (2008) reported a lower feed cost $/ \mathrm{kg}$ gain and a higher net profit values $/ \mathrm{kg}$ gain in lambs fed fungal treated diets when compared with control groups. The experiments conducted by Abdel-Aziz (2002) and El Shafie et al. (2007) also showed a reduction in feed cost by replacing $40 \%$ to $50 \%$ concentrate feed mixture with biologically treated rice or WS.

The digestibility of DM in our study was increased by $7 \%$ units on TMR2 diets, which is closer to that (10\%) found by Fazaeli et al. (2002) in cattle consuming fungal treated WS diets and that found by Kafilzadeh et al. (2009) in sheep consuming Pleurotus florida treated palm leaves, respectively. Similarly, Mahesh and Mohini (2013) found that feeding WS supplemented with Crinipellis sp. to Sahiwal calves significantly increased the digestibility of various nutrients and concluded that solid state fermentation with Crinipellis sp. holds the potential to upgrade the nutritive worth of WS.

Arora and Sharma (2009) conducted the solid state fermentation of WS collected from different regions of India with four different white rot fungi viz. Phlebia brevispora, $P$. fascicularia, $P$. floridensis, and $P$. radiate. They observed that $P$. brevispora was found to be the best organism that significantly enhanced the in vitro feed digestibility. In another experiment, $50 \%$ increase in in vitro digestibility of WS was observed with $P$. floridensis (Sharma and Arora, 2010). Okano et al. (2009) observed an increased in vitro digestibility of Madake bamboo (Phyllostachys bambusoides) when treated with white rot Ceriporiopsis subvermispora for 10 weeks in solid state fermentation chamber. Akinfemi (2010) reported that CP concentration was improved by treating peanut husk with $P$. ostreatus.

\section{CONCLUSIONS}

It is concluded that fungal (Arachniotus sp.) treatment of WS increases $\mathrm{CP}$ and ash contents while reducing the cell wall contents. Feeding rations with a 33\% replacement of WS with fungal treated WS in the TMR enhances growth performance in Nili Ravi buffalo calves by improving feed intake and nutrient digestibility. Beyond this level, losses in performance due to reduced dry matter intake owing to reduced digestibility and palatability may occur. It is also concluded that the biological treatments are preferable than physical and chemical methods for environmental conservation. We recommend the further extension of our findings in other livestock species to improve the overall livestock production potential.

\section{CONFLICT OF INTEREST}

We certify that there is no conflict of interest with any financial organization regarding the material discussed in the manuscript.

\section{ACKNOWLEDGMENTS}

This work was fully funded by the Higher Education Commission of Pakistan.

\section{REFERENCES}

Abdel-Azim, S. N., M. A. Ahmed, F. Abo-Donia, and H. Soliman. 2011. Evaluation of fungal treatment of some agricultural residues. Egypt J. Sheep Goat Sci. 6:1-13.

Abdel-Aziz, M. Y. 2002. Nutritional Studies on Biological Treatment of Agricultural by Product on Ruminants. M.Sc. Thesis, Zagazig University, Zagazig, Egypt.

Ahmed, S., F. Ahmad, and A. S. Hashmi. 2010. Production of microbial biomass protein by sequential culture fermentation of Arachniotus species and Candida utilis. Pak. J. Bot. 42:1225-1234.

Akinfemi, A. 2010. Bioconversion of peanut husk with white rot fungi: Pleurotus ostreatus and Pleurotus pulmonarius. Livest. Res. Rural Dev. 22:Article 49.

Akinfemi, A. and M. K. Ladipo. 2011. Effect of fungal treated maize cob on the performance of West African Dwarf Rams. In: International Conference on Research on Food Security, Natural Resource Management and Rural Development, University of Bonn, Bonn, Germany.

AOAC. 2006. Official Methods of Analysis, 18th ed., Association of Official Analytical Chemists, Washington, DC, USA.

Arora, D. S. and R. K. Sharma. 2009. Enhancement in in vitro digestibility of wheat straw obtained from different geographical regions during solid state fermentation by white rot fungi. BioResourc 4:909-920.

El-Kady, R. I., I. M. Awadalla, M. I. Mohamed, M. Fadel, and H. H. Abd El-Rahman. 2006. Effect of exogenous enzymes on the growth performance and digestibility of growing buffalo calves. Int. J. Agric. Biol. 8:354-359.

El-Shafie, M. H., A. A. Mahrous, and T. M. M. Abdel-Khalek. 2007. Effect of biological treatments for wheat straw on performance of small ruminants. Egypt J. Nutr. Feeds 10:635648.

Fazaeli, H., Z. A. Jelan, H. Mahmodzadeh, J. B. Liang, A. Azizi, 
and A. Osman. 2002. Effect of fungal treated wheat straw on the diet of lactating cows. Asian Australas. J. Anim. Sci. 15:1573-1578.

Fazaeli, H. and A. Shafeyi. 2003. Use of mushroom spent wheat straw compost as animal feed. In: 5th International Conference on Mushroom Biology and Mushroom Products, 8-12 April 2005, Shanghai, China.

Fazaeli, H. and S. A. Mirhadi. 2007. Nutritive value index of treated wheat straw with Pleurotus fungi fed to cow. Proc. Br. Soc. Anim. Sci. Southport, United Kingdom, April, 2007. p. 197.

Fouda, S. M. I. 2008. Studies of Nutrition on Sugar Cane Bagasse Previous Treated of Some Chemical and Biological Treatment. Ph.D. Thesis, Faculty of Agriculture, Al-Azhar University, Cairo, Egypt. pp. 115-116.

Kafilzadeh, F., F. Hozhabri, and A. Kabirifard. 2009. Effect of Pleurotus florida on in vitro gas production of wheat stubble and date palm leaf. Res. J. Biol. Sci. 4:37-41.

Kim, M.-K., H.-G. Lee, J.-A. Park, S.-K. Kang, and Y.-J. Choi. 2011. Recycling of fermented sawdust-based oyster mushroom spent substrate as a feed supplement for postweaning calves. Asian Australas. J. Anim. Sci. 24:493-499.

Mahesh, M. S. and M. Mohini. 2013. Nutritional evaluation of wheat straw treated with white-rot fungus Crinipellis sp. RCKSC in Sahiwal calves. Livest. Sci. http://dx.doi.org/ 10.1016/j.livsci.2013.11.021

Misra, A. K., A. S. Mishra, M. K. Tripathi, R. Prasad, S. Vaithiyanathan, and R. C. Jakhmola. 2007. Optimization of Solid State Fermentation of Mustard (Brassica campestris) Straw for Production of Animal Feed by White Rot Fungi (Ganoderma lucidum). Asian Australas. J. Anim. Sci. 20:208213.

Nisa, M., M. Sarwar, and M. A. Khan. 2004. Influence of ad libitum feeding of urea treated wheat straw with or without corn steep liquor on intake, in situ digestion kinetics, nitrogen metabolism, and nutrient digestion in Nili Ravi buffalo bull. Aust. J. Agric. Res. 55:229-236.

NRC. 2001. Nutrient Requirements of Dairy Cattle: Seventh Revised Edition. National Academy Press, Washington, DC, USA.
Okano, K., N. Ohkoshi, A. Nishiyama, T. Usagawa, and M. Kitagawa. 2009. Improving the nutritive value of madake bamboo, Phyllostachys bambusoides, for ruminants by culturing with the white-rot fungus Ceriporiopsis subvermispora. Anim. Feed Sci. Technol. 152:278-285.

Pakistan Economic Survey. 2013-2014. Government of Pakistan, Ministry of Food and Agriculture, Economic Adviser's Wing, Islamabad, Pakistan. pp. 13-15.

Ramírez-Bribiesca, J. E., A. S. Sánchez, L. M. Hernández-Calva, J. S. Alinas-Chavira, J. R. Galaviz-Rodriguez, R. G. CruzMonterrosa, and S. Vargas-López. 2010. Influence of Pleurotus ostreatus spent corn straw on performance and carcass characteristics of feedlot Pelibuey lambs. Ind. J. Anim. Sci. 80: 754-757.

Salman, F. M., R. I. El-Kadi, H. Abdel-Rahman, S. M. Ahmed, M. I. Mohamed, and M. M. Shoukry. 2008. Biologically treated sugar beet pulp as a supplement in goat rations. Int. J. Agric. Biol. 10:412-416.

Sarwar, M., M. A. Khan, and Z. Iqbal. 2002. Feed Resources for Livestock in Pakistan. Int. J. Agric. Biol. 4:186-192.

Selim, A. S. M., J. Pan, T. Takano, T. Suzuki, S. Koike, Y. Kobayashi, and K. Tanaka. 2004. Effect of ammonia treatment on physical strength of rice straw, distribution of straw particles and particle-associated bacteria in sheep rumen. Anim. Feed Sci. Technol. 115:117-128.

Shaukat., S., M. A. Bajwa, M. A. Waqar, and T. Sohail. 2006. Production, optimization, purification and characterization of glucomalyase from Arachniotus sp. J. Chem. Soc. Pak. 28:368-373.

Sharma, R. K. and D. S. Arora. 2010. Production of lignocellulolytic enzymes and enhancement of in vitro digestibility during solid state fermentation of wheat straw by Phlebia floridensis. Bioresour. Technol. 101:9248-9253.

Van Soest, P. J., J. B. Robertson, and B. A. Lewis. 1991. Methods for dietary fiber, neutral detergent fiber, and nonstarch polysaccharides in relation to animal nutrition. J. Dairy Sci. 74:3583-3597.

Younas, M. and M. Yaqoob. 2005. Feed resources of livestock in the Punjab, Pakistan. Livest. Res. Rural Dev. 17:Article 18. 